\section{Hjertefunksjon hos langtidsoverlevere etter brystkreft}

\author{
Nyere behandlingsformer er sannsynligvis forbundet med lavere risiko \\ for hjertesykdom enn tidligere metoder.
}

Det har lenge vært kjent at strålebehandling og cellegift kan være kardiotoksisk, men effekten av nyere behandling er mindre studert. I mitt doktorarbeid undersøkte vi dette i to grupper som fikk forskjellige typer strålebehandling.

I gruppe 1 sammenliknet vi 1566 kvinner med to forskjellige, i dag utdaterte opplegg i perioden 1975-91. Begge undergrupper fikk større doser per behandling enn det som hadde vært vanlig før, men med færre behandlingsdager, såkalt hypofraksjonert behandling. Den ene gruppen ble behandlet med større grad av hypofraksjonering enn den andre. Gruppen som mottok det mest hypofraksjonerte regimet, hadde økt risiko for død av koronar hjertesykdom, både sammenlignet med de andre pasientene og med kontrollpersonene. Funnene taler for at moderat grad av hypofraksjonering ikke gir økt dødelighet av hjertesykdom selv etter mer enn 20 års oppfølging.

Gruppe 2 inkluderte 236 kvinner som fra 1998 til 2002 fikk behandling mer lik dagens opplegg. Ved CT-undersøkelse ble det ikke funnet økt mengde kalk i koronararteriene (en tidlig markør på hjerte- og karsykdom) enn hos friske kontrollpersoner. Det ble heller ikke påvist forskjeller i systolisk funksjon ved ekkokardiografi, men diastoliske markører var signifikant dårligere hos pasientene enn hos kontrollpersonene.

Funnene gir grunn til å tro at risikoen for hjertesykdom etter moderne behandling er mindre enn tidligere. I studier med lengre oppfølgingstid bør man undersøke hva dårligere diastolisk hjertefunksjon betyr på lang sikt.

Kristin Holm Tjessem

ktjessem@gmail.com

\title{
Hvordan lete etter kreftmedisiner som fungerer best sammen?
}

\section{Ved hjelp av en datamodell kan kreftmedisiner som fungerer synergis- tisk, oppdages.}

Moderne kreftmedisiner kan virke ved å påvirke signalstrømmen i celler og bremse signaler som gir cellevekst, eller øke signaler som bremser cellevekst. Et problem i klinisk arbeid har vært at effekten av slike medisiner gjennomgående er kortvarig, og det er vanskelig å vite hvilke medisinkombinasjoner som fungerer best sammen.

I mitt doktorgradsarbeid ønsket vi å finne en metode som viser hvilke kombinasjoner av kreftmedisiner som fungerer best. Det er umulig å teste alle kombinasjoner blindt, siden antall kombinasjoner øker raskt med antall enkeltmedisiner tilgjengelig.

For å løse problemet lagde vi en datamodell som kan brukes til å simulere signaltrafikk i en kreftcelle - og som dermed kan brukes til å simulere effekten av medisiner som påvirker signaltrafikken, både som enkeltmedisiner og i par. Med denne model- len kunne vi for en kreftcellelinje gå fra biomarkørmålinger til prediksjoner av medikamentsynergier. Vi testet 21 parvise kombinasjoner og fant at metoden korrekt klassifiserte 20 av 21 responser som synergistiske eller ikke-synergistiske, validert i cellelinjer og dyreforsøk, og vi fant både kjente og tidligere ikke-beskrevne synergier.

Resultatene danner grunnlaget for vår nye plattform ved Norges teknisk naturvitenskapelige universitet - DrugLogics - hvor målet er todelt. For det første vil vi utvikle verktøy som hjelper oss og legemiddelindustrien med å rangere kombinasjoner med størst potensial for å være fulltreffere i kliniske studier. For det andre vil vi bruke vår metode til å skreddersy behandlingen for den enkelte pasient.

\section{Åsmund Flobak}

asmund.flobak@stolav.no

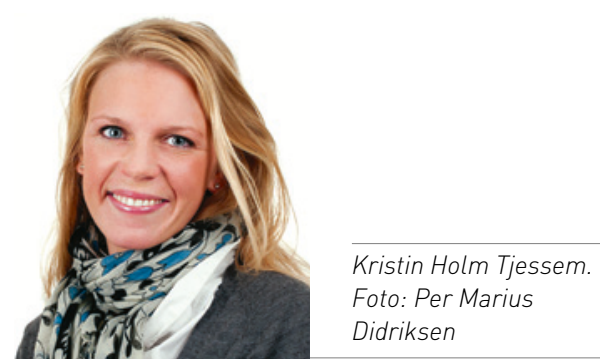

Disputas

Kristin Holm Tjessem disputerte for ph.d.graden ved Universitetet i Oslo 17.3.2016. Tittelen på avhandlingen er: Long-term cardiac function in breast cancer survivors.

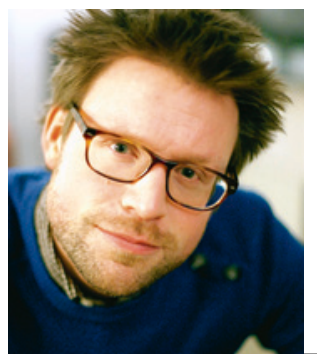

Åsmund Flobak Foto: Sivelin Kiølstad

\section{Disputas}

Åsmund Flobak disputerte for ph.d.-graden ved Norges teknisk-naturvitenskapelige universitet 16. mars 2016. Tittelen på avhandlingen er Systems medicine: from modeling systems perturbation to predicting drug synergies. 